\title{
Sensitivitas dan Spesifisitas Metode KOH 20\% + Tinta Parker Blue Black Dibandingkan dengan KOH 20\% pada Dermatomikosis Superfisialis
}

\author{
Firda Ulfa Ramadhani ${ }^{1}$, Diana Tri Ratnasari' ${ }^{2}$, Masfufatun ${ }^{3 *}$ \\ Fakultas Kedokteran Universitas Wijaya Kusuma Surabaya ${ }^{1}$ \\ Departemen Penyakit Kulit dan Kelamin, Fakultas Kedokteran, Universitas Wijaya Kusuma \\ Surabaya ${ }^{2}$ \\ Departemen Biokimia Fakultas Kedokteran Universitas Wijaya Kusuma Surabaya ${ }^{3}$ \\ *e-mail: masfufatun@uwks.ac.id
}

\begin{abstract}
Abstrak
Dermatomikosis superfisialis adalah infeksi jamur superfisial yang mengenai kulit, kuku, dan rambut. Berdasarkan sifat patogen penyebabnya, penyakit ini dibagi menjadi golongan dermatofitosis, pitiriasis versikolor, dan kandidiasis. Penegakan diagnosis yang cepat sangat penting untuk pemberian terapi yang tepat. Pemeriksaan penunjang yang dilakukan secara direct meggunakan $\mathrm{KOH}$. Larutan $\mathrm{KOH} 20 \%$ tidak memberikan kontras warna yang baik menyebabkan elemen jamur terlihat transparan, sehingga dibutuhkan keahlian pemeriksa untuk mengintepretasikan hasil. Salah satu alternatif untuk meningkatkan sensitivitas dan spesifitas $\mathrm{KOH}$ adalah dengan menambahkan zat warna seperti tinta parker blue black. Penelitian ini bertujuan untuk mengetahui sensitivitas dan spesifisitas metode $\mathrm{KOH} 20 \%+$ tinta parker blue black dibandingkan dengan $\mathrm{KOH} 20 \%$ pada dermatomikosis superfisialis. Metode penelitian ini merupakan penelitian analitik menggunakan desain cross sectional dengan 30 subjek penelitian. Sampel diambil dari kerokan pada lesi dermatomikosis superfisialis, kemudian diperiksa dengan larutan $\mathrm{KOH} 20 \%$, dan $\mathrm{KOH} 20 \%$ + tinta parker blue black di Rumah Sakit Siti Khodijah Muhammadiyah Cabang Sepanjang dan Klinik dr. Makmuri Surabaya. Hasil penelitian menunjukkan sensitivitas $\mathrm{KOH} 20 \%$ dan $\mathrm{KOH} 20 \%$ + tinta parker blue black sebesar $86,67 \%$ dan $93,33 \%$, sedangkan hasil spesifisitas $\mathrm{KOH} 20 \%$ dan $\mathrm{KOH} 20 \%$ + tinta parker blue black sebesar $100 \%$ dan $100 \%$. Berdasarkan hasil penelitian makan dapat disimpulkan bahwa larutan $\mathrm{KOH} 20 \%+$ tinta parker blue black dapat digunakan sebagai pemeriksaan rutin untuk mendiagnosis dermatomikosis superfisialis karena memiliki sensitivitas dan spesifisitas yang tinggi.
\end{abstract}

Kata Kunci: dermatomikosis superfisialis, $\mathrm{KOH} 20 \%$, tinta parker blue black, sensitivitas; spesifisitas

\section{The Sensitivity and Specificity of KOH 20\% + Blue Black Parker Ink in Comparisson with $\mathrm{KOH} 20 \%$ Method for Superficial Dermatomycosis}

\begin{abstract}
Superficial dermatomycosis is a fungal infection of the skin, nail and hair. Based on the pathogen, this infection can be divided into dermatophytosis, phytiriasis versicolor and candidiasis. The rapid diagnosis for this infection is the key point to deliver the right theraphy. The supporting investigation for this infection can be performed directly using $\mathrm{KOH}$. The $\mathrm{KOH} 20 \%$ solution has an
\end{abstract}


Sensitivitas dan Spesifisitas Metode KOH 20\% + Tinta Parker Blue Black Dibandingkan dengan... Firda Ulfa Ramadhani, Diana Tri Ratnasari, Masfufatun

indistict color contrast, that cause the fungal element seemed transparent. The observant expertise would be required for this case. The alternative method to enhance sensitivity and specificity of $\mathrm{KOH}$ is to add dyes such as Blue Black parker ink. The objectives of this research was to observe the sensitivity and specificity of $\mathrm{KOH} 20 \%$ + blue black parker ink in comparisson with $\mathrm{KOH} 20 \%$ method in superficial dermatomycosis. The research method was cross sectional design analitical obsevation with 30 research subjects. The samples were taken from superficial dermatomycosis lesion swabs. These samples were tested using $\mathrm{KOH} 20 \%$ solution and $\mathrm{KOH} 20 \%+$ blue black parker ink solution in Siti Khodijah Muhammadiyah Hospital, Sepanjang and dr. Makmuri Clinics, Surabaya. The results demonstrated that the sensitivity of $\mathrm{KOH} 20 \%$ solution and $\mathrm{KOH} 20 \%+$ blue black parker ink solution were $86.67 \%$ and $93.33 \%$, respectively. The specificity of $\mathrm{KOH} 20 \%$ solution and $\mathrm{KOH} 20 \%$ + blue black parker ink solution were $100 \%$ and $100 \%$, respectively. It can be concluded from the research that $\mathrm{KOH} 20 \%+$ blue black parker ink solution can be used for the routine diagnosis for superficial dermatomycosis due to the high sensitivity and specificity.

Keywords: superficial dermatomycosis, KOH 20\%, blue black parker ink, sensitivity, specificity.

\section{PENDAHULUAN}

Prevalensi kejadian dermatomikosis superfisialis masih cukup tinggi sebesar 89,2\% pada tahun 2013 di Divisi Mikologi URJ Kesehatan Kulit dan Kelamin RSUD Dr. Soetomo Surabaya pada tahun 2013 sebesar $89,2 \%$ (Rosida dan Evi, 2017). Dermatomikosis superfisialis adalah infeksi jamur superfisial yang mengenai kulit, kuku dan rambut, baik yang disebabkan oleh dermatofita maupun non-dermatofita (Jamaliyah et al, 2013). Penyakit dermatomikosis superfisialis dibagi menjadi tiga golongan yaitu dermatofitosis, pitiriasis versikolor, dan kandidiasis superfisialis (Sharma dan Richa, 2012).

$$
\text { Diagnosis dapat ditegakkan }
$$

berdasarkan anamnesis, pemeriksaan fisik, dan pemeriksaan penunjang. Pemeriksaan penunjang dermatomikosis superfisialis dapat dilakukan secara direct yaitu menggunakan kalium hidroksida (KOH) atau secara indirect yaitu menggunakan kultur jamur (Lukisari et al, 2010).

$\mathrm{KOH}$ merupakan metode pemeriksaan yang mudah, cepat, dan murah dalam mendeteksi keberadaan jamur (Miller et al, 1993 dalam Ardakani et al, 2016). Menurut Noviandini et al. (2017) konsentrasi yang sering digunakan sebagai pewarnaan adalah $\mathrm{KOH} 20 \%$. Pemeriksaan dengan $\mathrm{KOH}$ saja terkadang memiliki kekurangan yaitu tidak dapat menghasilkan kontras warna yang baik, sehingga membutuhkan keterampilan yang lebih untuk menafsirkannya (Shwetha et al, 2017).

Oleh karena itu, $\mathrm{KOH}$ dikombinasi dengan tambahan pewarna tinta parker yang 
ISSN 1978-2071 (Print); ISSN 2580-5967 (Online) Jurnal Ilmiah Kedokteran Wijaya Kusuma 9(2) : 218-228, September 2020

akan menambah kontras warna biru antara elemen jamur dengan sekitarnya sehingga memudahkan pembacaan. Oleh karena itu, pemeriksaan rutin yang dilakukan saat ini adalah $\mathrm{KOH} 20 \%$ + tinta parker blue black (Noviandini et al, 2017). Penelitian ini merupakan pemeriksaan untuk mengetahui sensitivitas dan spesifisitas larutan $\mathrm{KOH} 20 \%$ dan $\mathrm{KOH} 20 \%$ + tinta parker blue black dalam mengevalusi elemen jamur.

\section{BAHAN DAN METODE}

Penelitian ini merupakan suatu penelitian analitik menggunakan desain cross sectional. Penelitian ini dilakukan di Rumah Sakit Siti Khodijah Muhammadiyah Cabang Sepanjang dan Klinik dr. Makmuri pada Bulan September - Desember 2019. Populasi penelitian ini adalah pasien dengan dermatomikosis superfisialis dan non dermatomikosis superfisialis yang datang ke Poliklinik Kulit dan Kelamin, yang memenuhi kriteria penelitian yaitu pasien dengan semua usia dan tidak mengonsumsi obat anti jamur.

Bahan pemeriksaan diambil pada bagian tubuh yang terinfeksi yang sebelumnya sudah di swab dengan alkohol 70\% kemudian dilakukan lakukanlah teknik pengerokan atau scrapping pada lesi kulit atau kuku, sedangkan pada rambut menggunakan teknik trichogram (hair pluck) dengan cara mencabut beberapa helai rambut di daerah pinggir lesi menggunakan pinset atau needle holder. Siapkan dua objeck glass. Setelah itu gunakan scalpel untuk mengambil sampel dan meletakkannya pada dua objeck glass. Lakukan pemeriksaan $\mathrm{KOH} 20 \%$ dengan cara teteskan larutan tersebut (satu tetes) diatas spesimen yang sudah diletakkan diatas kedua objeck glass. Pada objek pertama langsung ditutup dengan kaca penutup (sudah diberi label), sedangkan pada objeck glass kedua teteskan tinta parker blue black 1:1 secara merata lalu tutup dengan kaca penutup (sudah diberi label), diamkan sampel selama 10-15 menit dalam suhu ruang kemudian diperiksa menggunakan mikroskop cahaya mulai dengan perbesaran awal dibawah 40x untuk melihat bentukan mikroskopis masing-masing jamur.

\section{HASIL}

Selama kurun waktu 3 bulan didapatkan 30 pasien yang sesuai dengan kriteria inkusi, yang terdiri dari 15 pasien dermatomikosis superfisialis dan 15 pasien non dermatomikosis superfisialis. Jenis kelamin terbanyak adalah perempuan. 
Sensitivitas dan Spesifisitas Metode $\mathrm{KOH} 20 \%$ + Tinta Parker Blue Black Dibandingkan dengan...

Firda Ulfa Ramadhani, Diana Tri Ratnasari, Masfufatun

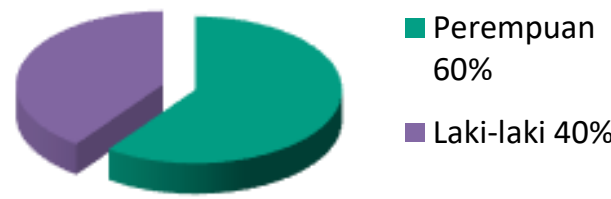

Gambar 1. Distribusi Subjek Penelitian Berdasarkan Jenis Kelamin

Kelompok umur terbanyak adalah umur 31-40 tahun yaitu sebanyak 10 pasien (33,33\%). Umur paling rendah adalah 12 tahun, sedangkan umur paling tinggi adalah 60 tahun.

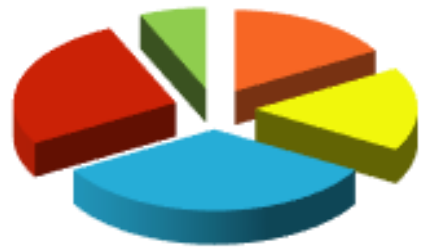

$11-20$ th $16,67 \%$

$21-30$ th $16,67 \%$

$31-40$ th $33,33 \%$

- $41-50$ th $26,67 \%$

$51-60$ th $6,66 \%$

Gambar 2. Distribusi Subjek Penelitian Berdasarkan Umur

Keluhan utama terbanyak pada pasien adalah bercak gatal. Bercak yang sering ditemukan adalah berwarna merah sebanyak 17 pasien (56,67\%), kemudian diikuti berwarna putih sebanyak 13 pasien (43,33\%). Morfologi elemen jamur terbanyak adalah hifa/arthoconidia, diikuti spaghetti \& meatballs kemudian spora/blastospora dan budding yeast.
Tabel 1. Morfologi Jamur

\begin{tabular}{ccc}
\hline Morfologi & KOH 20\% & $\begin{array}{c}\text { KOH 20 + Tinta } \\
\text { Parker Blue Black }\end{array}$ \\
\hline $\begin{array}{c}\text { Hifa / } \\
\text { Arthroconidia } \\
\text { Spaghetti \& } \\
\text { meatballs }\end{array}$ & $6(37,5 \%)$ & $7(41,19 \%)$ \\
Spora/blastospora & $3(18,75 \%)$ & $3(17,64 \%)$ \\
Budding yeast & $3(18,75 \%)$ & $3(17,64 \%)$ \\
\hline Total & $16(100 \%)$ & $17(100 \%)$ \\
\hline
\end{tabular}

Pada $\mathrm{KOH} 20 \%$ + tinta parker blue black didapatkan hasil positif 14 pasien \& negatif 1 pasien. $\mathrm{KOH} 20 \%$ didapatkan hasil positif 13 pasien \& negatif 2 pasien. Pada non dermatomikosis superfisialis baik dengan pewarnaan $\mathrm{KOH} 20 \%$ + tinta parker blue black maupun $\mathrm{KOH} 20 \%$ dari 15 pasien memberikan hasil negatif (true negative) dan positif (false positive) 0 pasien.

KOH 20\% + Tinta Parker Blue Black $\mathrm{KOH} 20 \%$

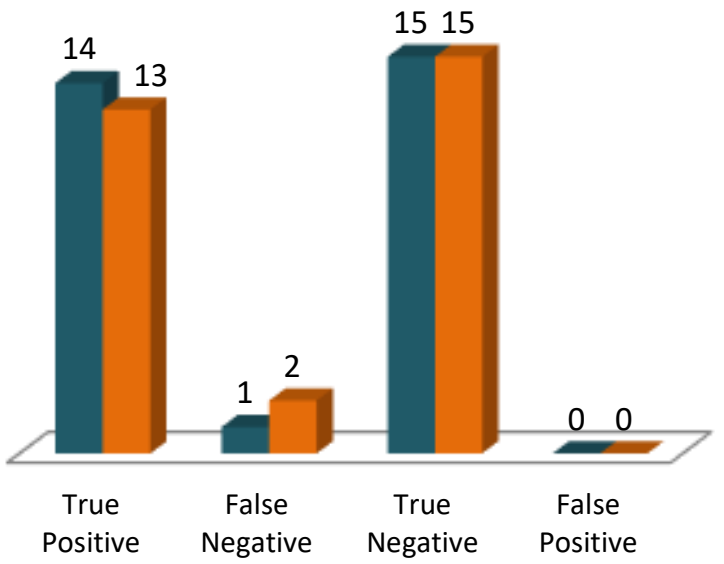

Gambar 3. Pemeriksaan $\mathrm{KOH} 20 \%$ dan $\mathrm{KOH} 20 \%+$ Tinta Parker Blue Black 
ISSN 1978-2071 (Print); ISSN 2580-5967 (Online) Jurnal Ilmiah Kedokteran Wijaya Kusuma 9(2) : 218-228, September 2020

Pada dermatofitosis positif 7 dari 8 pasien pada pewarnaan $\mathrm{KOH} 20 \%$ + tinta parker blue black dan positif 6 dari 8 pasien pada pewarnaan $\mathrm{KOH}$ 20\%. Pada pitiriasis versikolor dan kandidiasis memberikan hasil positif $100 \%$ baik pada pewarnaan $\mathrm{KOH} 20 \%$ + tinta parker blue black maupun $\mathrm{KOH} 20 \%$.

\section{Positif Negatif}

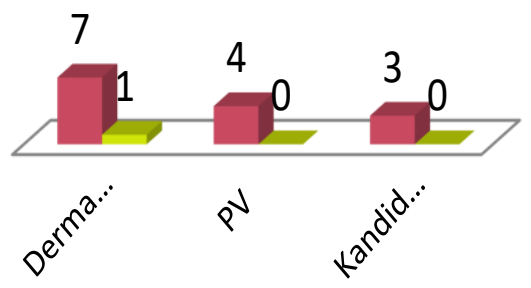

Gambar 4. Pemeriksaan $\mathrm{KOH} 20 \%$ + Tinta Parker Blue Black

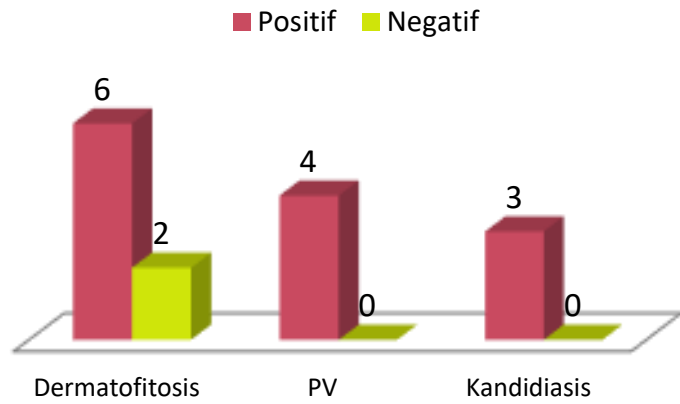

Gambar 5. Pemeriksaan $\mathrm{KOH} 20 \%$

Dari data hasil diatas maka dapat dilakukan perhitungan menggunakan rumus sensitivitas dan spesifisitas.
Tabel 2. Sensitivitas dan Spesifisitas KOH 20\% +

\begin{tabular}{cccc}
\multicolumn{3}{c}{ Tinta Parker Blue Black } & Total \\
\hline Hasil Uji & \multicolumn{2}{c}{ Status } \\
& $\begin{array}{c}\text { Dermatomikosis } \\
\text { Superfisialis }\end{array}$ & \\
\cline { 2 - 3 } & $(+)$ & $(-)$ & \\
\hline $\begin{array}{c}\mathrm{KOH} 20 \%+\text { tinta } \\
\text { parker blue black } \\
(+)\end{array}$ & 14 & 0 & 15 \\
$\begin{array}{c}\text { KOH 20\% + tinta } \\
\text { parker blue black }(-\end{array}$ & 1 & 15 & 15 \\
) & & & \\
\hline Total & 15 & 15 & 30 \\
\hline
\end{tabular}

Tabel 3. Sensitivitas dan Spesifisitas KOH 20\%

\begin{tabular}{cccc}
\hline Hasil Uji & \multicolumn{2}{c}{$\begin{array}{c}\text { Status } \\
\text { Dermatomikosis } \\
\text { Superfisialis }\end{array}$} & Total \\
& $(+)$ & $(-)$ & \\
\cline { 2 - 3 } & 13 & 0 & 15 \\
\hline $\mathrm{KOH} \mathrm{20 \%} \mathrm{(+)}$ & 2 & 15 & 15 \\
\hline $\mathrm{KOH} \mathrm{20 \%} \mathrm{(-)}$ & 15 & 15 & 30 \\
\hline Total & & &
\end{tabular}

Berdasarkan hasil perhitungan menggunakan rumus diatas maka didapatkan sensitivitas $\mathrm{KOH} 20 \%$ dan $\mathrm{KOH} 20 \%$ + tinta parker blue black masing-masing sebesar $86,67 \%$ dan 93,33\%. Sedangkan untuk spesifisitas $\mathrm{KOH}$ $20 \%$ dan $\mathrm{KOH} 20 \%$ + tinta parker blue black masing-masing sebesar $100 \%$ dan $100 \%$.

\section{PEMBAHASAN}

Penelitian Crespo dan Florencio (2006) mengatakan bahwa penegakan suatu diagnosis penyakit perlu dilakukan anamnesis, pemeriksaan fisik dan pemeriksaan penunjang termasuk untuk mendiagnosis suatu penyakit jamur yaitu dermatomikosis superfisialis. Pemeriksaan 
Sensitivitas dan Spesifisitas Metode KOH 20\% + Tinta Parker Blue Black Dibandingkan dengan... Firda Ulfa Ramadhani, Diana Tri Ratnasari, Masfufatun

penunjang dermatomikosis superfisialis dapat dilakukan secara direct yaitu menggunakan kalium hidroksida $(\mathrm{KOH})$ atau secara indirect yaitu menggunakan kultur jamur (Lukisari et al, 2010). Penelitian Shwetha et al (2017) juga mengungkapkan bahwa pemeriksaan dengan $\mathrm{KOH}$ saja terkadang memiliki kekurangan yaitu tidak dapat menghasilkan kontras warna yang baik, sehingga membutuhkan keterampilan yang lebih untuk menafsirkannya. Sehingga pada penelitian ini dilakukan pemeriksaan penunjang menggunakan $\mathrm{KOH} 20 \%+$ tinta parker blue black untuk dibandingkan dengan $\mathrm{KOH} 20 \%$.

Selama kurun waktu 3 bulan didapatkan 30 pasien yang sesuai dengan kriteria inkusi untuk menjadi subjek penelitian. Pada Gambar 1 distribusi jenis kelamin terbanyak pada subjek penelitian adalah perempuan sebanyak $60 \%$. Penelitian Hidayati et al (2009) mengatakan bahwa jenis kelamin terbanyak pada dermatomikosis superfisialis adalah perempuan dibandingkan dengan laki-laki. Sedangkan penelitian Agustine (2012) mengatakan bahwa jenis kelamin terbanyak adalah laki-laki. Berdasarkan data diatas dapat dikatakan bahwa insidens distribusi jenis kelamin pada penyakit dermatomikosis superfisialis sangat bervariasi.
Pada penelitian ini berdasarkan Gambar 2 distribusi kelompok umur terbanyak 31-40 tahun yaitu sebanyak (33,33\%). Kelompok umur 25-44 tahun merupakan kelompok usia produktif yang banyak mempunyai faktor predisposisi, misalnya pekerjaan basah, trauma, dan banyak berkeringat, sehingga risiko untuk menderita dermatomiksosis superfisialis lebih besar dibandingkan dengan kelompok umur lainnya (Hidayati et al, 2009).

Gejala klinis yang sering mucul pada subjek penelitian berupa bercak gatal sebesar $100 \%$ dengan warna terbanyak adalah berwarna merah sebanyak $56,67 \%$. Hasil penelitian tersebut didukung oleh data dari penelitian yang dilakukan di Divisi Mikologi Unit Rawat Jalan (URJ) Kesehatan Kulit dan Kelamin RSUD $\mathrm{Dr}$ Soetomo Surabaya yang menunjukkan bahwa keluhan terbanyak pasien mikosis superfiialis pada tahun 2011 sampai dengan 2013 adalah gatal sebanyak $83,1 \%$ dan bercak kemerahan sebanyak 34,2\% (Rosida dan Evy, 2017).

Pemeriksaan dikatakan positif apabila ditemukan hifa atau arthrospora pada dermatofitosis (Putriningsih dan I, 20018). Pada pitiriasis versikolor akan menunjukkan gambaran hifa/miselia pendek menyerupai huruf $i, v$,dan j, serta spora bulat dengan jumlah banyak dan bergerombol (spaghetti 
ISSN 1978-2071 (Print); ISSN 2580-5967 (Online) Jurnal Ilmiah Kedokteran Wijaya Kusuma 9(2) : 218-228, September 2020

and meat ball) (Rosida dan Evy, 2017). Sedangkan pada kandidiasis paling banyak ditemukan bentukan blastospora $(56,06 \%)$ selain itu ditemukan spora, pseudohifa dan budding yeast (Soetojo dan Astari, 2016).

Pemeriksaan secara mikroskopis pada Tabel $1 \mathrm{KOH} \mathrm{20 \%} \mathrm{+} \mathrm{tinta} \mathrm{parker} \mathrm{blue} \mathrm{black}$ dan $\mathrm{KOH} 20 \%$ didapatkan elemen jamur yang paling banyak berbentuk hifa/arthroconidia, diikuti spaghetti \& meatballs, kemudian spora/blastospora \& budding yeast. Hasil tersebut sesuai dengan jumlah dermatomikosis terbanyak adalah dermatofitosis 8 pasien $(53,33 \%)$, pitiriasis versikolor 4 pasien $(26,67 \%)$ dan kandidiasis 3 pasien (20\%). Hasil tersebut didukung oleh penelitian Noviandini et al (2017) yang mengatakan bahwa penyakit terbanyak yang dialamai pasien yaitu dermatofitosis 32 pasien $(71,1 \%)$, PV 10 pasien $(22,2 \%)$, dan kandidiasis kutis 3 pasien $(6,7 \%)$.

Pasien dengan penyakit dermatofitosis berjumlah 8 orang. Pada pemeriksaan $\mathrm{KOH}$ $20 \%+$ tinta parker blue black didapatkan hasil positif 7 pasien $(87,5 \%)$ dengan sebagain dari elemen jamur berwarna biru dan sisi lain berwarna transparan (Gambar 6a) kemungkinan hal ini disebabkan oleh elemen jamur yang kurang mampu menyerap warna tinta parker blue black, sedangkan pada $\mathrm{KOH}$ $20 \%$ didapatkan hasil positif 6 pasien (75\%) dengan elemen biru berwarna transparan (Gambar 6b).

Penelitian Tambosis dan Christopher (2012) mengatakan bahwa saat ini pewarnaan dengan $\mathrm{KOH} 20 \%$ + tinta parker blue black kurang menghasilkan kontras warna yang baik untuk mewarnai beberapa elemen jamur penyebab dermatomikosis superfisialis sehingga dibutuhkan pemeriksa yang sudah berpengalaman untuk membaca serta menginterpretasi hasil. Penelitian tersebut didukung oleh penelitian Noviandini et al (2017) pada $\mathrm{KOH} \mathrm{20 \%} \mathrm{+} \mathrm{tinta} \mathrm{parker}$ blue black memberikan warna transparan lebih banyak pada sediaan elemen jamur dibandingkan dengan warna biru (Gambar 7a). Sedangkan pada $\mathrm{KOH} \mathrm{20 \%} \mathrm{(Gambar} \mathrm{7b)}$ hanya memberikan warna transparan pada elemen jamur (Kurade et al, 2006).

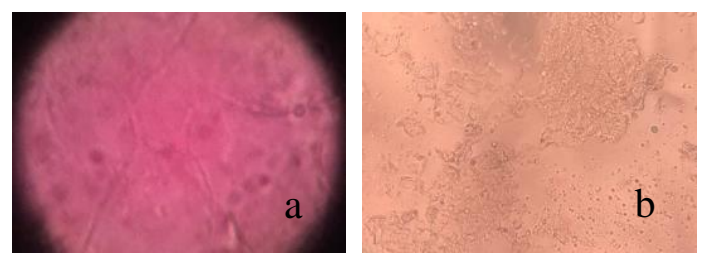

Gambar 6. Dermatofitosis (hasil survei 2019) : a. $\mathrm{KOH} 20 \%$ + Tinta Parker Blue Black, b. KOH 20\%
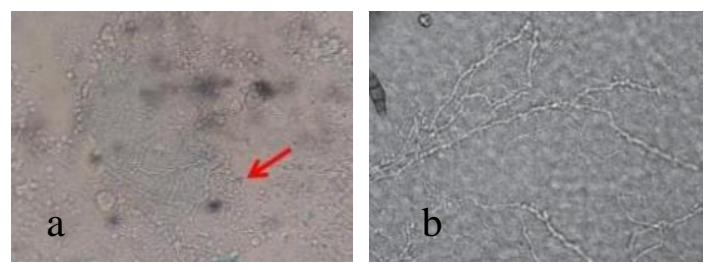

Gambar 7. Dermatofitosis (hasil penelitian lain): a. $\mathrm{KOH} 20 \%$ + Tinta Parker Blue Black (panah: hifa panjang), b. $\mathrm{KOH} 20 \%$ 
Sensitivitas dan Spesifisitas Metode KOH 20\% + Tinta Parker Blue Black Dibandingkan dengan... Firda Ulfa Ramadhani, Diana Tri Ratnasari, Masfufatun

Pada pitiriasis versikolor didapatkan hasil positif $100 \%$ baik pada $\mathrm{KOH} 20 \%+$ tinta parker blue black maupun $\mathrm{KOH} 20 \%$. Selain itu, elemen jamur pada pitiriasis versikolor terwarnai sangat baik berwarna biru dibandingkan elemen jamur lainnya pada pewarnaa $\mathrm{KOH} 20 \%$ + tinta parker blue black (Gambar 8a), sedangkan pada $\mathrm{KOH} 20 \%$ tetap berwarna transparan (Gambar 8b). Menurut Noviandini et al (2017) umumnya hanya sediaan yang berasal dari pitiriasis versikolor elemen jamur akan berwarna jelas lebih biru dibandingkan dengan jamur lainnya pada $\mathrm{KOH} 20 \%$ + tinta parker blue black (Gambar 9a). Temple dan Wesley (2019) mengatakan elemen jamur pada pitiriasias versikolor tampak berwarna transparan (Gambar 9b).
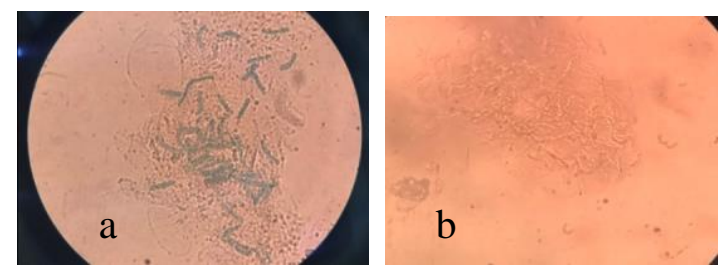

Gambar 8. Pitiriasis Versikolor (hasil survei 2019): a. $\mathrm{KOH} 20 \%$ + Tinta Parker Blue Black, b. $\mathrm{KOH} 20 \%$
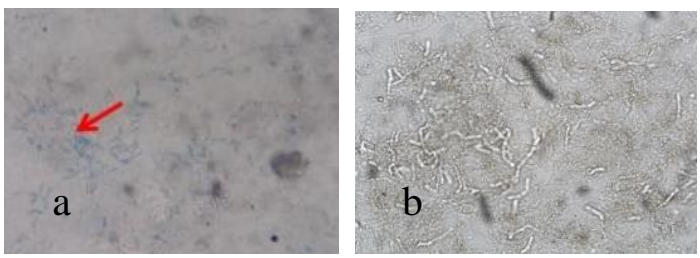

Gambar 9. Pitiriasis Versikolor (hasil penelitian lain) : a. $\mathrm{KOH} 20 \%$ + Tinta Parker Blue Black (panah: spaghetti \& meatballs appearance), b. $\mathrm{KOH} 20 \%$
Pada kandidiasis didapatkan hasil positif $100 \%$ pada $\mathrm{KOH} 20 \%$ + tinta parker blue black dan $\mathrm{KOH} 20 \%$. Elemen jamur bewarna biru pada $\mathrm{KOH} 20 \%$ + tinta parker blue black (Gambar 10a) dan transpraran pada $\mathrm{KOH} 20 \%$ (Gambar 10b). Penelitian Noviandini et al (2017) mengatakan bahwa elemen jamur kandidiasis berwarna transparan pada semua sediaan (Gambar 11a). Sedangkan pada KOH 20\% (Gambar 11b) elemen jmaur menunjukkan warna transparan (Das et al, 2019).
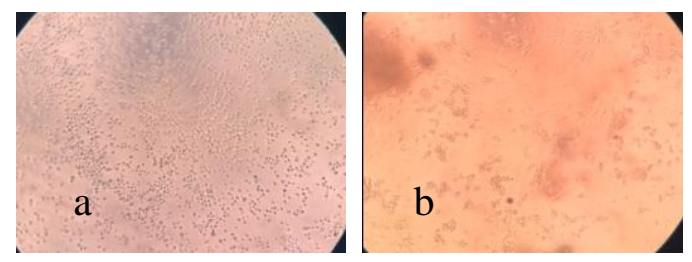

Gambar 10. Kandidiasis (hasil survei 2019): a. $\mathrm{KOH} 20 \%$ + Tinta Parker Blue Black, b. $\mathrm{KOH} \mathrm{20 \%}$
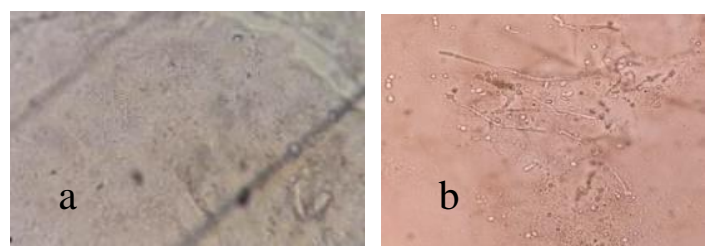

Gambar 11. Kandidiasis (hasil penelitian lain): a. $\mathrm{KOH} 20 \%$ + Tinta Parker Blue Black, b. $\mathrm{KOH} 20 \%$

Berdasarkan Gambar 3 hasil pemeriksaan dari 15 pasien dermatomikosis superfisialis dinyatakan 13 pasien positif (true positive) dan 2 orang negatif (false negative) pada pemeriksaan $\mathrm{KOH} 20 \%$, sedangkan pada pemeriksaan $\mathrm{KOH} 20 \%+$ tinta parker blue black dinyatakan 14 pasien 
ISSN 1978-2071 (Print); ISSN 2580-5967 (Online) Jurnal Ilmiah Kedokteran Wijaya Kusuma 9(2) : 218-228, September 2020

positif (true positive) dan 1 orang pasien negatif (false negative). Pada hasil penelitian dari 15 pasien non dermatomikosis superfisialis dinyatakan negatif (true negative) sebanyak 15 orang (100\%) dan posiitif (false positive) sebanyak 0 pasien (0\%) pada semua pemeriksaan baik $\mathrm{KOH} 20 \%$ maupun $\mathrm{KOH} 20 \%$ + tinta parker blue black.

Adanya false positive dan false negative, kemungkinan hal ini dapat terjadi adanya overlapping gejala klinis suatu penyakit, pengambilan kerokan atau swab yang kurang banyak, waktu melisiskan yang kurang lama, serta faktor larutan yang

KOH 20\% $\square \mathrm{KOH} 20 \%+$ Tinta Parker Blue Black

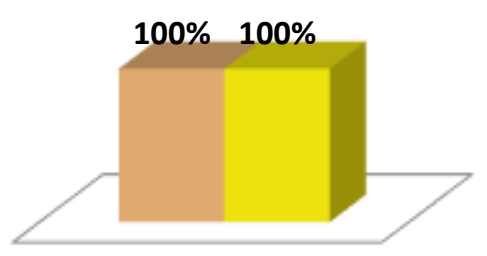

Gambar 12. Spesifisitas

$-\mathrm{KOH} 20 \%-\mathrm{KOH} 20 \%+$ Tinta Parker Blue Black

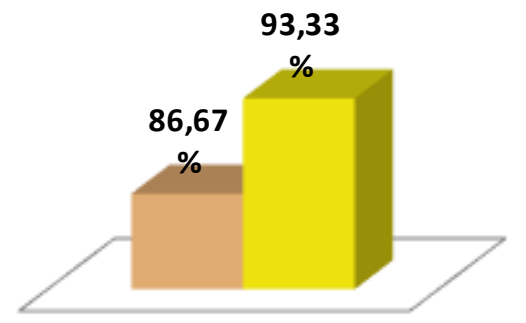

Gambar 13. Sensitivitas digunakan seperti $\mathrm{KOH} 20 \%$ saja tanpa penambahan pewarna tinta parker blue black maka akan memberikan hasil transparan sehingga dapat diartikan hasil yang negatif.

Pada penelitian Shwetha et al (2017) mengungkapkan bahwa nilai sensitivitas pewarnaan $\mathrm{KOH}$ yaitu 93\% dan spesifisitas $\mathrm{KOH}$ yaitu $77 \%$. Akan tetapi penelitian Tambosis dan Christopher (2012) mengatakan bahwa sensitivitas dan spesifisitas $\mathrm{KOH}$ yang dicampur dengan tinta parker blue black sebesar 48\% dan 96\% pada dermatomikosis

(Gambar 13).

\section{KESIMPULAN}

$\mathrm{KOH} 20 \%$ + tinta parker blue black merupakan pemeriksaan yang baik untuk mendiagnosis dermatomikosis superfisialis karena memiliki sensitivitas dan spesifisitas yang tinggi.

\section{DAFTAR PUSTAKA}

Ardakani ME, Ghaderi N, Kafaei P, 2016. The Diagnostic Accuracy of Potassium Hydroxide Test in Dermatophytosis. Basic \& Clinical Medicine. 5(2): 4-6.

Agustine R, 2012. Perbandingan Sensitivitas dan Spesifisitas Pemeriksaan Sediaan Langsung $\mathrm{KOH}$ 20\% dengan Sentrifugasi dan Tanpa Sentrifugasi 
Sensitivitas dan Spesifisitas Metode KOH 20\% + Tinta Parker Blue Black Dibandingkan dengan... Firda Ulfa Ramadhani, Diana Tri Ratnasari, Masfufatun

pada Tinea Kruris. Tesis. Padang: Fakultas Kedokteran Universitas Andalas.

Crespo-Erchiga V, dan Florencio VD, 2006. Malassezia yeasts and pityriasis versicolor. Curr Opin Infect Dis. 19(2): 139-47.

Das KH, Mangayarkarasi V, and Sen M, 2019. Antifungal Resistant in Non-albicans Candida Species are Emerging as a Threat To Antenatal Women with Vulvovaginal Candidiasis. Biomedical \& Pharmacology Journal. 12(3): 1369-1378.

Hidayati AN, Suyoso S, Hinda D, Sandra E, 2009. Mikosis Superfisialis di Divisi Mikologi Unit Rawat Jalan Penyakit Kulit dan Kelamin RSUD Dr. Soetomo Surabaya Tahun 20032005. Berkala Ilmu Kesehatan Kulit \&amp; Kelamin. 21(1): 1-8.

Jamaliyah, Wardani MK, Roesyanto ID, 2013. Profil Dermatomikosis Superfisial pada Pekerja Pabrik Tahu di Desa Mabar, Kecamatan Medan Deli. Majalah Kedokteran Nusantara. 46(2): 74-76.

Kurade SM, Amladi SA, Miskeen AK, 2006. Skin Scraping and a Potassium Hydroxide Mount. Indian J Dermatol Venereol Leprol. 72(3): 238-241.
Lukisari C, Setyaningtyas D, Djamhari $M$, 2010. Penatalaksanaan Kandidiasis Oral disebabkan Candida tropicalis pada Anak dengan Gangguan Sistemik. Dentofasial. 9(2): 78-85.

Noviandini A, Suyoso S, Astari L, 2017. Pemeriksaan Pewarnaan Kalium Hidroksida $\quad(\mathrm{KOH}) \quad 20 \%+$ Tinta Parker ${ }^{\mathrm{TM}}$ Blue-Black, Chicago Sky Blue (CSB), dan Kultur Jamur pada Dermatomikosis Superfisialis. Berkala IImu Kesehatan Kulit dan Kelamin - Periodical of Dermatology and Venereology. 29(1): 21-29.

Rosida F, dan Ervianti E, 2017. Penelitian Retrospektif: Mikosis Superfisialis. Berkala IImu Kesehatan Kulit dan Kelamin - Periodical of Dermatology and Venereology. 29(2): 117-125.

Sharma M, dan Sharma R, 2012. Profile of Dermatophytic and Other Fungal Infections in Jaipur. Indian Journal of Microbiology. 52(2): 270-274

Shwetha JV, Harsha TR, Khan SA, Ambrica R, 2017. Comparison of Chicago Sky Blue (Novel Stain) with Calcoflour White and Pottasium Hydroxide Mount for Rapid Diagnosis of Dermatomy Dermatomucosis and Onychomycosis in a Tertiary Care Centre. International Journal of 
ISSN 1978-2071 (Print); ISSN 2580-5967 (Online) Jurnal Ilmiah Kedokteran Wijaya Kusuma 9(2) : 218-228, September 2020

Current Research. 9(2): 4686446868.

Soetojo SDR, dan Astari L, 2016. Profil Pasien Baru Infeksi Kandida pada Kulit dan Kuku. Berkala IImu Kesehatan Kulit dan Kelamin - Periodical of Dermatology and Venereology. 28(1): $34-41$

Tambosis E, dan Lim C, 2012. A Comparison of the Contrast Stains, Chicago Blue,
Chlorazole Black, and Parker Ink, for the Rapid Diagnosis of Skin and Nail Infections. International Journal of Dermatology. 51.

Temple RW, dan Cowan WC, 2019. Hyperpigmented Plaques. Arch Community Med Public Health. 5(1): 001-002. 